\title{
The Canadian health system and its financing ${ }^{1}$
}

\author{
Francisco Xavier Solórzano²
}
ABSTRACT This work stems from a brief visit in 1993 to the Canadian health services as part of the PAHO International Health Training Program and the subsequent research, discussion, and analysis relating to that experience. By no means is this paper an exhaustive account of the system, but rather a close look at one of its aspects: financing. The main objective is to identify some of the virtues and limitations of a health system that is considered one of the most efficient, effective, and equitable in the world.
Although the Canadian health system is financed by the federal government and the provin- cial governments, cost containment is a constant concern, since factors such as the growing use of highly complex technologies, hospital care, and long-term treatment of chronic and degenerative illnesses tend to increase costs.
The progressive reduction in the federal budget has led to more efficient use of resources and the rationalization of installed capacity. At the same time, the relative simplicity of the sys- tem's operation has permitted administrative costs to be kept low. In addition, alternative forms of care, such as local centers for community-based care, care at home and in special insti- tutions to promote the maximum level of self-sufficiency, and the use of volunteers, have been devised in order to partially control cost increases.
The people's participation in planning and decision-making permit them to guide the devel- opment of the health services. Nevertheless, given the current situation, it is essential that the system be modified to prepare it for the challenges the twenty-first century will bring.

In Canada, health care is provided by a cooperative national system financed jointly by public and private health insurance providers, system users, and the government (1). Because the Canadian Constitution delegates responsibility for health care to the provincial and territorial governments, there are in fact 12 interconnected health systems, each corresponding to one of the 10 provinces and two territories (Yukon and North-

\footnotetext{
1 This article was published in Spanish in this journal, 1997, Vol. 1, No. 3, pp. 180-185, with the title "El sistema de salud de Canadá y su financiamiento."

2 Formerly of the Pan American Health Organization, Public Policy and Health Program, Washington, D.C., U.S.A. Mailing address: P.O. Box 2535, Rockville, MD 20847, USA.
}

west Territories), plus one system under federal jurisdiction.

The Federal Government establishes the legal framework and basic principles governing the system, which the provinces and territories are free to observe with some degree of flexibility (1-3). The federal system also covers special groups-such as Indians, the armed forces, and the federal police (4). Within this framework, the provinces are charged with primary responsibility for administering, organizing, and providing health services and for financing and regulating the activities of health professionals. Despite the fact that the federal and provincial systems are independent and autonomous, all of them must comply with the basic principles of accessibility, integrated coverage, universality, portability, and public administration (5).

Financing is shared by the federal and the provincial or territorial governments. Federal legislation has been designed to ensure that all Canadian residents have access to needed medical care through a health insurance system financed by tax revenues. Regardless of income or ability to pay, all residents are in principle entitled to medical and hospital services-in addition to such diagnostic, surgical, and dental procedures (6) as are considered medically necessary within the context of the coverage provided by the system. 
A basic characteristic of the Canadian health system is that it covers all Canadian residents. Although the Canadian population is small relative to the country's physical size, it tends to be concentrated in urban areas, primarily in the south and along the coasts, with low population densities prevailing elsewhere.

At the discretion of the provinces and local governments, health insurance plans providing additional coverage are available. However, a constitutional mandate prohibits denial of care to a Canadian resident, even though the individual does not have coverage or economic resources sufficient to cover the cost of care. In addition, a person's status as a resident of another country can never be used to justify denial of care.

\section{HEALTH SYSTEM EXPENSES}

Canada's per capita expenditures on health and the percentage of gross domestic product (GDP) allocated to health are among the highest in the world. For example, Canada's 1992 health expenditures were estimated at $9.5 \%$ of GDP, while in the United States the corresponding figure was $13 \%$ (7). If comparable amounts are converted into per capita expenditures, in 1991 Canada spent US\$ 2107 per person while the United States spent US\$ 2868 (Table 1). Comparison of these figures, as well as 1990 figures published for Canada by the World Bank (8), to those for other developed countries makes it clear that the percentages of GDP allocated to health by Canada and the United States are among the highest in the world. Besides being among the world's highest, along with those of Finland, Sweden, and Switzerland (8), per capita health expenditures in Canada and the U.S. have doubled over the past decade.

In 1990, total expenditures on health in Canada were distributed as follows: hospitals, 38\%; other institutions, $11 \%$; pharmaceuticals and equipment, $16 \%$; physicians, $15 \%$; dentists, $6 \%$; research activities, $1 \%$; administrative functions, $1 \%$; and other categories, $12 \%$.

TABLE 1. Cost and financing of health services in Canada and the United States, 1988 and 1991

\begin{tabular}{|c|c|c|c|}
\hline Indicator & Canada & United States & Year \\
\hline $\begin{array}{l}\text { Expenditures on health } \\
\text { (in US } \$ \times 10^{9} \text { ) }\end{array}$ & 56.9 & 751.8 & 1991 \\
\hline $\begin{array}{l}\text { Expenditures on health } \\
\text { (as a \% of GDPa) }\end{array}$ & 9.9 & 13.2 & 1991 \\
\hline $\begin{array}{l}\text { Per capita expenditures } \\
\text { (in US\$) }\end{array}$ & 2107 & 2868 & 1991 \\
\hline $\begin{array}{l}\text { Hospital services: } \\
\text { Available beds } \\
\text { (per } 1000 \text { inhabitants) }\end{array}$ & 5 & 3.9 & 1988 \\
\hline $\begin{array}{l}\text { Admissions } \\
\text { (per } 1000 \text { inhabitants) }\end{array}$ & 137 & 130 & 1988 \\
\hline $\begin{array}{l}\text { Patients undergoing surgery } \\
\text { (per } 1000 \text { inhabitants) }\end{array}$ & 70 & 63 & 1988 \\
\hline $\begin{array}{l}\text { Average stay } \\
\text { (in days) }\end{array}$ & 10.7 & 7.2 & 1988 \\
\hline Occupancy rate (\%) & 82 & 66 & 1988 \\
\hline $\begin{array}{l}\text { Cost per stay } \\
\text { (in US\$) }\end{array}$ & 3660 & 4207 & 1988 \\
\hline $\begin{array}{l}\text { Cost per day } \\
\text { (in US\$) }\end{array}$ & 334 & 744 & 1988 \\
\hline
\end{tabular}

Source: Canadian Ministry of Health, 1993.

a Gross domestic product.

In the United States, expenditures in these same categories were allocated as follows: hospitals, $38 \%$; other institutions, $8 \%$; pharmaceuticals and equipment, $10 \%$; physicians, $19 \%$; dentists, 5\%; research activities, $2 \%$; administrative functions, $6 \%$; and other categories, $12 \%{ }^{3}$ The considerable difference in administrative expenses accounts for a large part of the difference in the total per capita Canadian and U.S. expenditures on health $(9,10)$.

\section{HEALTH SYSTEM FINANCING}

Close to $95 \%$ of the health expenditures involving physicians and hospitals are covered by tax revenues. However, the public sector covers a smaller percentage of total health expenditures-about $75 \%$ around the turn of the decade-with the remainder being paid directly by individuals and private insurance plans (11). More re-

\footnotetext{
Data from Canadian Ministry of Health (Health Canada), 1993.
}

cently, private expenditures have grown faster than public expenditures, and as a result public participation has dropped to $72 \%$ (1). Within this framework, the public sector assumes the primary role in financing health insurance, while the private sector pays for most medications, dental care, and prescription eyeglasses $(11,12)$.

Public sector expenditures on health, financed primarily by taxes, are shared by the provincial and federal governments (which pay $61 \%$ and $37 \%$, respectively, with local governments and workers' compensation funds accounting for the remaining 2\%). Distribution is based on population data and per capita GDP for the preceding three years (13). Federal health expenditures are covered primarily by what is known as the consolidated income fund, which obtains its revenue from various sources including customs duties, individual and corporate income taxes, and excise taxes.

Provincial health expenditures are covered primarily by general tax revenues. In Ontario, for example, $33 \%$ is provided by individual income taxes, 
$18 \%$ by sales taxes, and $7 \%$ by corporate income taxes. Other contributors include employers $(6 \%)$; the Federal Government (16\%); and other sources (20\%). According to data for 1993 provided by the Canadian Ministry of Health, small additional complementary sources include health insurance premiums (accounting for between 5\% and $20 \%$ of the expenditures in two provinces); salary-based contributions to health care; and fees charged for the room and board of patients requiring prolonged periods of hospitalization.

Another interesting feature of the Canadian system is that physicians and hospitals work independently in the private sector. Since the health system is based on the concept of a single payer, which in the case of Canada is the Provincial Government (with support from the Federal Government), a fee negotiated by mutual agreement between the government and the medical association has been established for each medical/surgical procedure. Approximately $95 \%$ of all physicians practicing within the Canadian system work on a fee-for-service basis, with the rest receiving their compensation in the form of training or a salary. Only $1 \%$-those engaged primarily in the fields of public health, health promotion, and community health-are dependent on local government and receive a fixed salary.

The establishment of fixed fees for various professional services has created some discontent among physicians, whose standard of reference is the income earned by their U.S. colleagues, despite the fact that they are the best-paid professionals in Canada (14). One result of this discontent is an observable trend among physicians toward requesting unjustified medicalsurgical consultations and procedures (6) in order to increase income.

A number of systems are currently being designed to control costs, including payment of lower fees for professional services provided by physicians whose annual incomes exceed a certain amount. Using this latter approach, a discount of onethird of the fee charged by physicians earning more than Can\$ 400000 is applied, while a two-thirds discount is applied in the case of those earning more than Can\$ 450 000. In addition, lower rates, equivalent to those charged by general physicians, have been established for specialists in cases where patients have not been referred from the primary level (15).

\section{THE HEALTH SERVICE STRUCTURE}

Hospitals, particularly those providing care to patients with acute problems, have a public side, depending on government contracts, and their administrators are partially responsible to the Ministry of Health. However, because of their origins, hospitals are actually private, not-for-profit corporations with directors who are professional administrators and who report to a board of directors that includes community representatives.

Each hospital receives an annual allotment of funds from the province in the form of an overall package based on prior expenditures. This provides administrators with some flexibility in managing their resources. However, budgets are also increased annually, in accordance with the government's fiscal situation, in order to respond to situations in which hospital services require additional support. Beyond this, it is sometimes possible to obtain supplementary financing for specialized programs. In addition, some provinces offer incentives to hospitals that adopt cost containment procedures. One such incentive is a savings and retention program that authorizes hospitals to redistribute resources saved as a result of efficient management to other operating areas of the hospital, instead of returning them to the provincial treasury (13).

Development of specialized programs has enabled the government to use financial mechanisms to promote regionalization and rationalization of certain services-such as open heart surgery, organ transplants, and nuclear magnetic resonance imaging. In the case of ultramodern technologies such as computerized axial tomography and magnetic resonance imaging, even capital investments come from private sources and are authorized only when the installed capacity of available services has been exceeded. However, outside the area of such highly complex and expensive services requiring rationalization of government expenditures, interinstitutional coordination is generally minimal, and only rarely is an appropriate rendering of accounts provided to municipal or regional planning organizations.

Besides nongovernment hospitals specializing in mental health, there are also psychiatric hospitals operated by the provincial governments. A system of day hospitals is currently being promoted, with the number of available beds being reduced, in order to increase the cost-effectiveness of psychiatric care.

Hospitals, which are not authorized to conduct for-profit activities, must devise other strategies to overcome budgetary limitations. Such strategies include using a large number of volunteers for administrative and community service activities and raising funds through publicity campaigns, donations, and sale of auxiliary diagnostic, treatment, and rehabilitation services to other facilities lacking the necessary installed capacity to provide such services. Within this context, fund-raising has in fact become a unique and specialized activity with its own sphere of action for the hospital organization. In any case, it is important to recognize that one of the virtues of the system is the relative harmony between public and private elements: Health professionals practice their professions with relative freedom; hospitals are administered by private groups representing the communities they serve; and the government provides financing for hospital and professional activities.

\section{COST CONTROL}

In recent years, the budget allocated to hospitals by the provincial governments has progressively decreased in absolute terms, which has forced these 
facilities to make increasingly efficient use of their resources and to increasingly rationalize the use of their installed capacity. To contain costs, hospitals are assigning their health teams to community care activities that provide all health care in the home, where justified, in order to avoid situations where patients with noncritical complaints crowd hospital emergency rooms. Another strategy used by hospitals to ensure appropriate referral of patients and appropriate purchase and sale of complementary services is clear definition of areas of specialization. Within this context, it is noteworthy that while the private sector is empowered to install and sell diagnostic imaging services, in October 1995 the Federal Government acquired the capacity to regulate the supply of such services by reducing its contribution to provincial budgets (1).

In addition, initiatives aimed at providing care to the elderly in nursing homes as well as their own homes have been implemented. Although such initiatives depend largely on support provided by volunteer personnel, room and board, particularly in nursing homes, has a cost. However, that cost is determined in such a way that even elderly patients dependent on a pension as their sole source of income are able to pay for room and board and still have funds available for out-of-pocket expenses. The problem, therefore, lies in a scarcity of available beds and long waiting lists.

Methodologic proposals have also been advanced to rationalize resource use and increase the effectiveness of resource planning. The Province of Ontario, for example, has adopted an approach for distributing resources and planning health care based on population needs (16). Within the context of changes currently being implemented in the system to help contain escalating costs, there are enormous differences between this system and those systems in place in Latin America, particularly with regard to financial resources available for operating health service facilities. As an example of such differences, in 1992 the operating budget for the North York General
Hospital in Toronto, which has about 500 beds and a user population of approximately 250000 inhabitants, was Can\$ 94 million, a budget comparable to those of some Ministries of Health in developing countries such as Nicaragua or Paraguay that serve populations 20 times larger $(17,18)$.

Nevertheless, Canada is currently immersed in an economic crisis. In the health sector, this has manifested itself primarily in the form of reduced federal contributions to health insurance financing. This has forced the provinces to resort to other financing options-such as rationalization of the use of highly complex services, promotion of primary health care strategies, and implementation and strengthening of community health care services. For example, Quebec has organized a health care network that operates through Local Community Service Centers (LCSC)-these latter being facilities designed to focus integrated, multidisciplinary attention on social problems affecting the community such as drug addiction, unemployment, AIDS, and other diseases. These care facilities, with very limited staffing and resources, base their operations on demand. Despite these limitations, the teamwork of LCSC professionals has provided a worthwhile model; and although the Quebec LCSC experience has been the most extensive to date, other provinces are attempting to replicate it.

At present, the health systems of Canada and the United States face crises due primarily to increased cost of services. In 1994 Canada introduced a series of cost containment measures that have led to dissatisfaction and unrest among both health personnel and patients. Among other things, these measures include reduction in the number of hospital beds, encouragement of short-stay surgery, increased use of outpatient services, tighter control over the compensation paid to health personnel, more intensive use of lower-paid professionals, planning of medical specialization areas by territory, and implementation of incentives to practice medicine in rural areas $(6,19)$.
The challenge facing Canada over the coming years consists, therefore, in being able to provide its people with health care that is effective, equitable, and as inexpensive as possible. It should be pointed out that the administrative simplicity of the Canadian health system has helped keep administrative costs down, which in turn has led to considerable resource savings. Use of the single-payer system also reflects an effort to contain costs by controlling both the amount of services provided and their price (7), as does promotion of inexpensive diagnostic and treatment methods (through such measures as restriction by provincial drug formularies of the use of expensive drugs when cheaper options are available). However, over time the system's interesting mix of public and private elements, in the form of health insurance that is government-financed and relatively cheap but dependent on private providers, has led to increases in both per capita expenditures and use of services (20).

\section{CONCLUSIONS}

The Canadian Government guarantees its residents access to health services and furnishes the infrastructure and resources necessary for the private sector to provide those services. Users are actively involved in planning and decision-making through their representation on the boards of directors of health service facilities.

In order to contain rising costs, most provinces have adopted a policy of freezing expenditures. In the case of Ontario, for example, the overall increase in hospital budgets has remained below the rate of inflation, at a rate of about $1 \%$ (5). In addition to measures aimed at controlling budgetary growth, an agreement has also been reached to place a cap on salaries and to discount a given percentage of the annual income of physicians earning more than a set amount.

Within this context, an important current cost-containment initiative is based on community support strategies. Such strategies clearly constitute 
a valid option in the face of the increasing costs of providing health services to a gradually aging population with its growing burden of chronic and degenerative illnesses requiring long, costly, and complex procedures. The measures adopted include establishment of community support services to reinforce the efforts of health personnel and volunteers.

Despite the high costs currently facing the Canadian health system, the quality of service, the high level of consumer satisfaction, and especially the level of human development achieved by the population would appear to fully justify the magnitude of the current expenditure on health. The present challenge created by budgetary reductions consists of finding a way to husband resources without affecting the quantity and quality of care.

To sum up, over the past two decades Canada has managed to maintain a relatively satisfactory balance between the free and entrepreneurial health care model seen in the United States and the single, integrated systems such as those existing in Great Britain and Sweden, in which the government exercises stricter control. The Canadian system is oriented toward social welfare, i.e., directed towards satisfying the basic needs of most of its people (21). If its virtues and deficiencies are averaged out, the Canadian system appears superior to that of the United States. The difference lies in the basic elements of each system: Whereas the U.S. system staunchly defends individual freedom, the Canadian system is more concerned with collective well-being. One of the great problems of the moment is the steady increase in health expenditures, control over which is made difficult by population aging, the growing need for hospital care, and high-volume consumption of new technologies.

The current decade represents a crucial juncture in which there is an immediate need to correct certain problems of the Canadian health system in order to avoid progressive deterioration in the accessibility and quality of care and to prevent further cost increases. Toward this end various reforms have been proposed: development of health promotion and disease prevention activities to complement curative services; implementation of cost-containment measures and reduction of the government deficit; complete rationalization, integration, regionalization, and restructuring of the health services, with increased emphasis on their efficiency and effectiveness and on alternative ways of providing services; decentralization of responsibilities; and careful management of the adoption and use of technologic innovations, focusing particularly on costeffectiveness. Whatever the reforms adopted, the end purpose is of course the satisfaction of the needs of the population, taking advantage of every opportunity to reduce both the risk and the burden of morbidity. ${ }^{4}$

Acknowledgments. While any error or omission remains my sole responsibility, I wish to extend my sincere appreciation for comments and suggestions to all those who helped with the preliminary drafts of this manuscript and, particularly, to the three anonymous reviewers who provided guidance for producing this final version.

\footnotetext{
4 Since the initial preparation of this manuscript, the Canadian health system has been affected by a series of political and economic changes. It is currently possible to observe a marked trend toward reduction of government contributions to financing the system, which has in turn increased private sector participation. This situation has given rise to a conflict between federal legislative provisions and their application at the provincial level. To be sure, the Canadian health system has gone through a process of continuous adaptation in an effort to satisfy the needs of its public. However, it is difficult to predict at this time the future of a health system that, despite its limitations, constitutes a model for many countries.
}

\section{REFERENCES}

1. National Forum on Health. The public and private financing of Canada's health system. Ottawa: National Forum on Health; 1995.

2. Ministry of Supply and Services. Choose Canada: for world class health products and services. Ottawa: Ministry of Supply and Services; 1992.

3. Health Canada. Canadian report to the Special Meeting on Health Sector Reform. Washington, DC: 29-30 September 1995.

4. Sutherland R, Fulton J. Spending smarter and spending less: policies and partnerships for health care in Canada. Ottawa: The Health Group; 1994.

5. Fulton J. Canada's health system: bordering on the possible. Washington, DC: Faulkner \& Gray's Healthcare Information Center; 1993.

6. Heidemann E. The Canadian health care system: cost and quality. Bull Pan Am Health Organ 1994;28:169-176.
7. Chernomas R, Sepehri A. An economist's brief guide to the recent debate on the Canadian health care system. Int J Health Serv 1994; 24:189-200.

8. World Bank. World development report 1993: investing in health. Washington, DC: World Bank; 1993.

9. Himmelstein DM, Woolhandler S. Cost without benefit: administrative waste in U.S health care. N Engl J Med 1986;314:441-445.

10. Evans RG, Lomas J, Barer ML, et al. Controlling health expenditures: the Canadian reality. N Engl J Med 1989;320:571-577.

11. Naylor D. The Canadian health care system: a model for America to emulate? Health Econ 1992;1:19-37.

12. Evans R. Health care in the Canadian community. In: Bennett A, Adams O. Looking north for health: what we can learn from Canada's health care system. San Francisco: Jossey-Bass; 1993.
13. Díaz-Muñoz R, Levcovich M, Lima Quintana L, Ramos S. Sistemas de salud en proceso de reforma. Buenos Aires: Organización Panamericana de la Salud; 1994.

14. Graig LA. Health of nations. Washington, DC: Congressional Quarterly; 1993.

15. United States General Accounting Office. Primary care physicians: managing supply in Canada, Germany, Sweden, and the United States. Report presented to the Chairman of the House Committee on Government Operations by the U.S. General Accounting Office. Washington, DC: USGAO; May 1994.

16. Roemer MI. National health systems throughout the world. Annu Rev Public Health 1993; 14:335-353.

17. North York General Hospital. Meeting the challenge: North York General Hospital annual report 1991-92. North York: North York General Hospital; 1992 
18. Organización Panamericana de la Salud. Vol II. Las condiciones de salud en las Américas. Washington, DC: PAHO; 1994. (Scientific Publication 549).

19. Contandriopoulos AP, Champagne F, Denis J, el al. Regulatory mechanisms in health care systems of Canada and other industrialized countries: description and assessment. Ottawa: University of Ottawa; 1994.
20. Newbold KB, Eyles J, Birch S. Equity in health care: methodological contributions to the analysis of hospital utilization within Canada. Soc Sci Med 1995;40:1181-1192.

21. Eyles J, Birch S. A population needs-based approach to health-care resource allocation and planning in Ontario: a link between policy goals and practice? Can J Public Health. 1993;84:112-117.
Manuscript received on 6 September 1995. Revised version accepted for publication on 11 June 1996.

RESUMEN El presente trabajo es el fruto de una breve visita realizada en 1993 a los servicios de salud de Canadá como parte del Programa de Formación en Salud Internacional de la OPS, y de un subsiguiente ejercicio de investigación, discusión y análisis. No pretende

El sistema de salud del en modo alguno ser exhaustivo, sino más bien aproximarse a uno de los aspectos Canadá y su financiamiento relevantes del sistema: su financiamiento. El objetivo central es identificar algunas de las virtudes y limitaciones de un sistema de salud que se considera de los más eficientes, efectivos y equitativos del mundo.

A pesar de que el gobierno federal y los gobiernos provinciales financian el sistema de salud canadiense, la contención de costos es una preocupación constante, ya que factores como el uso creciente de tecnologías de alta complejidad, la atención hospitalaria y el tratamiento prolongado de las enfermedades crónicas y degenerativas contribuyen a aumentar los costos.

La progresiva reducción del presupuesto federal ha llevado a un uso más eficiente de los recursos y a la racionalización de la capacidad instalada. Asimismo, la relativa sencillez con que funciona el sistema ha permitido mantener bajos los costos administrativos. Además, se han ideado otras formas de atención, como los centros locales de atención comunitaria, la atención domiciliaria y en asilos para promover la autosuficiencia en la medida de lo posible, y el uso de personal voluntario, para controlar parcialmente el incremento de los costos.

La participación de la población en la planificación de los servicios de salud y en la toma de decisiones le permite orientar su desarrollo. Dada la situación actual, resulta imprescindible, sin embargo, modificar el sistema para adecuarlo a los desafíos planteados por el siglo XXI. 